\title{
Kesetaraan Gender Ditinjau dari Sudut Pandang Normatif dan Sosiologis
}

\author{
Zulkifli Ismail ${ }^{1}$, Melanie Pita Lestari ${ }^{2}$, Panti Rahayu ${ }^{3}$, Fransiska Novita \\ Eleanora $^{4 *}$ \\ 1,2,3,4 Fakultas Hukum, Universitas Bhayangkara Jakarta Raya, Jakarta, Indonesia \\ *E-mail: siska_ita@yahoo.com
}

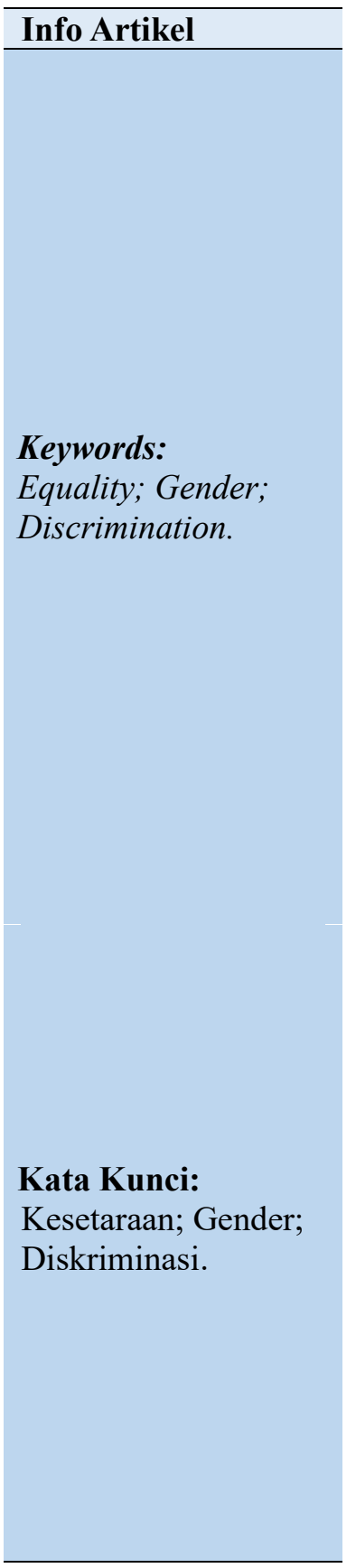

\begin{abstract}
This study discusses that gender equality must be paired with justice and justice, between men and women must be equal and there must be no differences or contradictions. A normative study looking at it from the perspective of the following law is that submission will discuss the rights of a woman, everyone has equal rights without exception, and those rights have existed since man is in a supported reserve. Research methods using the normative juridical method by reviewing the literature and legislation, where the findings or results have met the requirements for the rights of everyone listed in the regulations of Law Number 39 of 1999, but viewed from the point of view seen sociological that in society assumes that gender equality can occur if each party considers to be responsible, their duties and roles. While the usefulness of this research provides benefits and participation of law enforcers, the community must not represent gender differences or injustice in the community, all people have the same rights, novelty in this study agrees and then gender in community life to prioritize and prioritize there will be the right to life, because that right is a very determined right granted to all people such as the right not to increase torture, get education, health, and eliminate the perception of gender inequality in any field or area of life, because everyone is the same and supports, in the field of law, and also government.

\begin{tabular}{l}
\hline Abstrak \\
Penelitian ini bertujuan untuk mengetahui bahwa kesetaraan gender \\
harus berasaskan kepada kemanusiaan dan keadilan, antara laki-laki \\
dan perempuan harus sejajar dan tidak boleh ada perbedaan atau \\
diskriminasi. Kajian yang normatif melihat dari suatu sudut pandang \\
undang-undang yaitu adanya perlindungan akan keberadaan dari \\
hak-hak seorang wanita, setiap orang mempunyai persamaan hak \\
tanpa terkecuali, dan hak tersebut sudah ada sejak manusia berada \\
dalam kandungan ibunya. Metode penelitian dengan menggunakan \\
metode yuridis normatif dengan mengkaji literatur dan peraturan \\
perundang-undangan, dimana temuan atau hasilnya bahwa walaupun \\
sudah adanya pengaturan akan hak-hak setiap orang secara tertulis di \\
dalam aturan Undang-Undang Nomor 39 Tahun 1999 tetapi jika \\
ditinjau dari sudut pandang sosiologis bahwa dalam masyarakat \\
beranggapan bahwa kesetaraan gender dapat terjadi jika masing- \\
masing pihak menyadari akan adanya tanggungjawab, tugas dan
\end{tabular}
\end{abstract}


peran masing-masing. Sedangkan kegunaan dari penelitian ini memberikan manfaat dan juga masukan kepada aparat penegak hukum, masyarakat bahwa tidak boleh adanya perbedaan atau ketidakadilan gender dalam masyarakat, semua orang mempunyai hak yang sama, kebaruan dalam penelitian ini kesetaraan akan gender dalam kehidupan harus lebih mengutamakan dan mengedepankan akan adanya ha-hak hidup, karena hak tersebut merupakan hak yang sangat mutlak diberikan kepada semua orang seperti hak untuk tidak mengalami penyiksaan, mendapatkan pendidikan, kesehatan, dan menghilangkan anggapan adanya ketidakadilan akan gender dalam bidang atau aspek kehidupan apapaun juga, karena semua orang sama dan berhak, dalam bidang hukum, dan juga pemerintahan.

\section{A. PENDAHULUAN}

Masalah mengenai kesetaraan gender pernah ada habisnya dan selalu menjadi isu di dalam segala bidang kehidupan, dan hal tersebut bukan hanya terjadi dei Negara Indonesia saja, melainkan sudah dalam cakupan luas, artinya setiap Negara juga memperjuangkan akan adanya keadilan dalam kesetaraan gender tanpa adanya diskriminasi, dalam memperlakukan atau memberikan hak-hak setiap orang. Sebenarnya sudah ada basis yang legal dalam menjamin akan adanya hak atau kesempatan laki-laki dan perempuan tanpa adanya perbedaan dari segala aspek bidang kehidupan yang ada, dan basis yang legal yang dimaksud tersebut sudah dituangkan dan sudah terlihat dalam Deklarasi Penghapusan dan Kekerasan Terhadap Perempuan ${ }^{1}$ yang telah dibuat dan disahkan Tahun 1993 oleh Perserikatan Bangsa Bangsa, tapi sangat disayangkan dengan adanya deklarasi itu tidak dipahami dan dikenak oleh masyarakat indonesia, sehingga jarang sekali dijadikan pedoman dan acuan dalam menyelesaikan setiap masalah yang berbasis gender.

Gender dan permasalahan yang ada didalamnya bukan membahas mengenai jenis kelamin perempuan dan laki-laki melainkan bagaimana agar adanya persamaan diantaranya tanpa adanya perbedaan, mendapatkan keadilan dan persamaan hak diantara keduanya, secara kodrat laki-laki dianggap lebih kuat dari perempuan, bisa diartikan lakilaki dapat memberikan perlindungan kepada perempuan, sedangkan perempuan dapat memberikan kelemahlembutannya kepada pihak kaum adam dan juga kepada anaknya. Tetapi yang justru terjadi adalah dengan ketidakadilan gender dan perbedaan tersebut bukannya lebih mendekatkan kedua jenis kelamin itu, tetapi yang terjadi malah sebaliknya, perempuan kerapkali dijadikan korban, baik korban dalam kekerasan rumah tangga, pelecehan seksual, perkosaan dan lain sebagainya, di mana pada intinya lebih mendiskriminasikan perempuan, padahal sekarang adalah zaman emansipasi wanita, artinya seorang perempuan tidak boleh lagi dijajah, bebas akan hak-haknya dan tidak dapat dibatasi oleh apapun dan dalam keadaan apapun ${ }^{2}$.

Perempuan dan laki-laki berhak mendapatkan hak-hak yang sama, sudah banyak aturan yang mengatur akan kesetaraan terhadap gender tersebut, dan bukan hanya itu saja, kaum pria dan wanita berhak mendapatkan hak yang sama, Negara, Pemerintah dan Hukum sudah melindungi warganya dalam mendapatkan akan keberadaan hak-haknya, seorang perempuan setidaknya bukan hanya diberikan kebebasan saja dalam menggunakan haknya, tetapi setidaknya mendapatkan perlindungan akan hukum, perlindungan untuk selalu dijaga agar tidak ada tindakan sewenang-wenang siapapun

1 Prantiasih, A. (2012). "Hak Asasi Manusia Bagi Perempuan”, Jurnal Pendidikan Pancasila dan Kewarganegaraan, 25 (1), h. 12.

${ }^{2}$ Luhulima, A. S. (2014). CEDAW : Menegakkan Hak Asasi Perempuan, Jakarta : Yayasan Pustaka Obor Indonesia, h. 17. 
terhadap perempuan, dan tidak dibiarkan memperlakukan perempuan secara tidak benar yaitu dengan bersikap kasar atau tidak senonoh, karena bagaimanapun harus ada saling menghargai dan menghormati antara satu dengan yang lainnya tanpa melihat adanya perbedaan apapun ${ }^{3}$.

Penghormatan dan pengakuan akan kesetaraan terhadap gender sebenarnya sudah harus dimulai sejak dini, sejak awal dan sudah harus ditanamkan sejak masih kanak-kanak dengan menjelaskan bahwa pria dan wanita adalah makhluk akan ciptaan Tuhan Yang Maha Esa, sehingga harus saling menjaga satu dengan yang lainnya dan tidak memperbolehkan melukai atau menimbulkan ketersinggungan. Pengakuan yang mensyaratkan bahwa adanya perlindungan secara hukum kepada perempuan dapat di artikan bahwa hak dari setiap orang akan selalu dijaga, dengan kata mempersilahkan atau memperbolehkan untuk menggunakan hak-haknya namun jangan sampai melanggar atau bertentangan dengan hak orang lain. Walaupun pada dasarnya, sudah ada perlindungan akan gender, tetapi secara prakteknya masih banyaknya terjadi penyimpanganpenyimpangan yang ada, baik dalam ranah skop terkecil yaitu keluarga bahkan sampai di tingkat atas, ternyata bahwa perempuan akan hak-haknya masih dibatasi, masih mendapatkan tempat yang bisa dianggap belum sepenuhnya, bukan hanya pada perempuan saja bahkan bisa berdampak juga pada anak-anak, karena perempuan dan anak-anak masih sangat rentan dengan kekerasan, perlakuan yang tidak manusiawi sering mereka dapatkan, belum sepenuhnya aturan yang ada berpihak kepada mereka ${ }^{4}$.

Seringnya perempuan dianggap sebagai yang lemah, sehingga dalam segala hal tanpa disadari terjadinya atau munculnya tindakan diskriminasi, sebagai contoh, adanya anggapan jikalau ada masalah yang tidak dapat diselesaikan atau dipecahkan, maka perempuan akan menangis sebaliknya jika pihak laki-laki dalam menyelesaikan aau memecahkan masalah dengan kepala dingin, tanpa harus menangis, anggapan ini diartikan perempuan sangat lemah dan cengeng dalam menyelesaikan konflik yang ada, situasi seperti ini sering dikatakan bahwa perempuan sangatlah lemah dan rentan, bukan hanya itu saja adanya juga anggapan dalam masyarakat yang ada bahwa seorang perempuan atau wanita bersekolah dengan tinggi-tinggi tapi ujung-ujungnya masuk ke dapur juga, menjadi ibu rumah tangga, sehingga dapat diartikan masih adanya persepsi masyarakat yang melihat seorang perempuan lebih dominan mengurusi suami, anak, rumah tangganya dibandingkan mengenyam pendidikan yang tinggi

Padahal zaman sudah tidak seperti dulu, setiap orang entah itu laki-laki atau perempuan harus mendapatkan pendidikan setinggi-tingginya, artinya setiap orang berhak untuk meraih keberhasilan, berhak mendapatkan pendidikan dan pengajaran, tidak boleh ada yang menghalangi, karena perempuan juga ingin mandiri, dan pintar sama layaknya dengan yang lainnya, jadi tindakan diskriminasi, intimidasi atau ancaman sangat tidak diperbolehkan karena hal tersebut bertentangan ${ }^{5}$ dengan kesetaraan gender dan termasuk juga pelanggaran hukum, oleh karena itu kesetaraan gender merupakan hak setiap orang untuk mendapatkan akan hak-haknya.

Berdasarkan pendahuluan diatas, maka rumusan masalah yang akan di kaji adalah sebagai berikut: "Bagaimana kesetaraan gender di tinjau dari sudut pandang normatif dan sosiologis, dan Bagaimana kendala atau hambatan dalam kesetaraan gender"

3 Efendy, R. (2014). “Kesetaraan Gender Dalam Pendidikan”, Jurnal Al-Maiyyah, 07 (02), h. 147.

4 Hasan, B. (2019). “Gender dan Ketidakadilan", Jurnal SIGNAL, 7 (1), h. 65-66

5 Krisnalita, L. Y. (2018). "Perempuan, HAM, dan Permasalahannya Di Indonesia”, Binamulia Hukum, 7 (1), h. 72-73. 


\section{B. METODE PENELITIAN}

Penelitian ini menggunakan yuridis normatif yaitu dengan mengkaji literatur atau buku-buku beserta dengan peraturan perundang-undangan yang ada, yang berkaitan dengan masalah yang akan diteliti, sedangkan teknik dalam pengumpulan bahan hukum dilakukan dengan cara primer, sekunder dan tersier dan teknik analisis bahan hukum dengan studi kepustakaan dengan melakukan penelusuran terhadap bahan-bahan hukum yang ada yaitu dengan mengumpulkan bahan hukum yang ada, dan langkah selanjutnya adalah dilakukan pemetaan terhadap bahan-bahan hukum tersebut sesuai dengan pokok permasalahan ${ }^{6}$ yang ada.

\section{PEMBAHASAN}

\section{Kesetaraan Gender}

Istilah dari gender menimbulkan berbagai penafsiran yang berbeda-beda, dimana kata gender dalam istilah bahasa Indonesia berasal dari bahasa inggris "gender" diartikan sebagai jenis kelamin, ${ }^{7}$ dan mengacu dari pendapat yang diberikan oleh Mansour Faqih, memberikan arti bahwa gender merupakan suatu sifat yang memang melakta pada diri perempuan dan juga pada diri laki-laki di mana dapat di lakukan konstruksi baik dalam kultural dan juga dalam sosial. Sebagai contoh dalam diri perempuan dipandang dan dilihat sangatlah emosional, juga cantik dan juga lemah dan juga sebagainya. Sementara itu dalam diri pihak laki-laki lebih pandang sangatlah kuat, dan juga rasional, serta jantan dan perkasa, dan tidak boleh cengeng atau juga menangis. Sifat dan ciri yang dapat dipertukarkan dan adanya perubahan dari ciri dan sifat dapat terjadinya dari waktu ke waktu dan juga dari tempat ke tempat yang lain, bahakn tidak menutup kemungkinan dapat terjadi di dalam kelas masyarakat yang berbeda ${ }^{8}$.

Secara harfiah bahwa yang dimaksud dengan Kesetaraan gender merupakan suatu kesamaan akan kondisi yang ada bagi kaum laki-laki dan kaum perempuan untuk mendapatkan hak-haknya sebagai manusia, dan juga mampu berperan dan juga berpartisipasi baik dalam dalam segala kegiatan-kegiatan dalam aspek bidang politik, juga dalam hukum, bidang yang ekonomi, serta sosial dan budaya, juga dalam pendidikan dan aspek pertahanan dan juga keamanan nasional serta adanya kesamaan dalam menikmati pembangunan dan hasilnya. Terwujudnya akan adanya kesetaraan dalam gender tentunya ditandai diskriminasi yang tidak ada, baik di antara kaum perempuan dan laki-laki sehingga akses yang ada dapat mereka miliki, berpertisipasi teruka lebar dan adanya kesempatan, kontrol dan juga memperoleh manfaat pembangunan yang setara dan juga adil. Adapun berbagai indikator dalam gender dan kesetaraannya adalah sebagai berikut :

1) Adanya Akses; peluang atau kesempatan dalam menggunakan sumberdaya tertentu. Mempertimbangkan dan juga memperhitungkan bagaimana laki-laki dan perempuan medpaatkan sumberdaya tersebut secara merata dan juga adil, dalam bidang pendidikan adanya program beasiswa, dimana diberikan secara adil dan merata antara laki-laki dan perempuan untuk mendapatkannya.

\footnotetext{
6 Soekanto, S \& Mamudji, S. (2015). Penelitian Hukum Normatif (Suatu Tinjauan Singkat), Jakarta : Rajawali Pers Cetakan ke-17, h. 52.

7 M. Echols John dan Sadily, H. (1983). Kamus Inggris Indonesia, Jakarta: Gramedia, cet XII, h. 265

8 Fakih, M. (2007). Analisis Gender dan Transformasi Sosial, Yogyakarta: Pustaka Pelajar, h. 8-9.
} 
2) Partisipasi; Aspek dalam partisipasi merupakan suatu keikutsertaan dalam suatu kelompok atau orang tertentu dalam pengambilan keputusan. Disini dapat dilihat bahwa perempuan dan juga laki-laki apakah memang memiliki suatu peran yang sama atau tidak dalam mengambil suatu keputusan.

3) Kontrol; penguasaan atau juga wewenang atau kekuatan dalam pengambilan suatu keputusan yang ada. Pemegang jabatan dalam hal tertentu dapat dilihat didominasi oleh gender atau tidak.

4) Manfaat; merupakan manfaat atau kegunaan yang dapat dan juga dirasakan dan dinikmati secara penuh dan optimal. Di mana dalam keputusan tersebut yang telah di ambil oleh pihak sekolah dapat memberikan suatau kemanfataan adil dan sebaikbaiknya serta merata bagi laki-laki dan perempuan ${ }^{9}$.

\section{Kesetaraan Gender dalam Sudut Pandang dalam Normatif dan Sosiologis}

Jika merujuk pada pandangan yang normatif dimaksudkan bahwa kesetaraan gender didasarkan pada aturan dan norma yang berlaku, dimana sikap seseorang lebih berpedoman kepada loyalitas, kesetiaan, serta aturan dan kaidah yang berlaku di lingkungannya. Sudut dalam pandangan yang normatif memberikan pengertian bahwa adanya aturan yang mengikat seseorang untuk tidak melakukan penyimpangan atau melanggar suatu kaidah atau norma yang sudah ditetapkan. Ketaatan dan kesetiaan ditunjukkan dengan berpegang teguh pada prinsip-prinsip yang ada, dimana prinsipprinsip tesebut diadopsi dalam suatu peraturan hukum, yang mendasarkan pada keadilan, kepastian hukum dan kemanfaatan hukum, dan prinsip ${ }^{10}$ tersebut tercermin dalam aturan-aturan yang sudah ditetapkan oleh negara, dan jika dilanggar maka akan dikenakan sanksi bagi mereka yang melanggarnya.

Pesamaan hak antara laki-laki dan perempuan sudah diupayakan untuk semuanya mendapatkan apa yang menjadi hak-haknya serta adanya perlindungan hukum yang bersifat preventif dan juga represif, dimana perlindungan hukum yang preventif lebih menekankan adanya kesempatan yang diberikan kepada rakyat untuk mengajukan keberatan sebelum keputusan pemerintah mendapatkan bentuk yang definitive, sedangkan perlindungan yang bersifat represif adalah bentuk dari perlindungan hukum yang lebih ditujukan dalam penyelesaian suatu sengketa yang timbul ${ }^{11}$.

Kesetiaan serta berpegang teguh pada norma-norma atau aturan yang ada, diartikan juga adanya sikap taat hukum dan menyadari diri akan adanya persamaan hak antara yang satu dengan lainnya, kesadaran hukum yang timbul dikarenakan adanya sikap untuk saling membutuhkan, menghargai dan menjunjung tinggi akan hak-hak asasi manusia, dan menyadari sepenuhnya bahwa setiap orang tidak hanya mempunyai kelebihan saja tetapi juga ada kekurangan dalam dirinya, konsisten dan berpegang teguh pada prinsip hidup serta mengetahui bahwa sudah ada aturan yang mengikat untuk tidak melakukan hal-hal yang disebut dengan perbuatan pidana atau tindak pidana ${ }^{12}$.

Sebaliknya jika tidak taat hukum dan melanggar aturan-aturan hukum atau melakukan perbuatan yang dianggap masuk dalam ranah tindak pidana, tentunya akan diberikan hukuman yang sesuai dengan kesalahannya, dalam hal ini melakukan suatu

9 Ulfatun, H dan Najahan, M. (2017). “Gender And Politics : Keterlibatan Perempuan Dalam Pembangunan Politik", SAWWA, 12 (3), h. 415.

10 Graham, D. S. (2018). Keberagaman Gender di Indonesia, Jakarta : Yayasan Pustaka Obor Indonesia, h. 72.

11 Ibid, h. 82-83

12 Amalia, M. (2011). "Kekerasan Perempuan Dalam Perspektif Hukum Dan Sosiokultural”, Jurnal Wawsan Hukum, 25 (02), h. 401 
perbuatan atau penderitaan yang mengakibatkan seseorang terluka, cacat, kelumpuhan, bahkan kematian dan terbukti sudah terjadi tindak pidana, melakukan penyiksaan, pemukulan atau mengakibatkan penderitaan maka akan dipidana, ada pasal-pasal yang mengaturnya dalam Kitab Undang-Undang hukum Pidana (KUHP), serta ancaman hukuman berupa penjara dan denda ${ }^{13}$. Untuk menyatakan telah terjadi perbuatan yang dapat dipidana atau tindak pidana, selain terdapatnya barang bukti dan alat bukti yang ada, maka sudah terpenuhinya unsur-unsur dari suatu tindak pidana yang terjadi, yaitu :

a) Subyek, disebut sebagai subyek yaitu orang (person) dan juga Korporasi (badan usaha yang sah atau badan hukum)

b) Kesalahan, dimaksud disini yaitu karena dolus (kesengajaan), sengaja melakukan tindak pidana ada niat dan juga sudah direncanakan, sedangkan culpa (kelalaian), kurang hati-hati, akibat kurang hati-hati atau lalai dapat mengakibatkan seseorang menderita sakit, cacat dan mati.

c) Bersifat Melawan Hukum, bertentangan dengan aturan hukum yang ada, atau tidak sesuai dengan suatu larangan atau keharusan dalam hukum dan menyerang kepentingan dalam hukum, dan kata melawan hukum selalu dicantumkan dalam rumusan dalam delik.

d) Perbuatan tersebut sudah diatur dalam suatu peraturan, setiap perbuatan atau tindakan yang melanggar suatu aturan hukum, dan mengakibatkan perasaan tidak enak, kerugian, penderitaan serta adanya korban, tentunya sudah ada aturan yang mengaturnya, sesuai perbuatan yang dilakukannya baik sengaja atau tidak sengaja, dan dibutuhkan yang namanya pembuktian untuk menuntut apakah pelaku bersalah atau tidak.

e) Adanya waktu, tempat dan keadaan, yang dikenal dengan locus delicti dan tempus delicti, kapan perbuatan atau tindakan dilakukan dimana tempatnya atau wilayahnya serta jam berapa dilakukan dan bagaimana keadaan pelaku apakah sudah dewasa atau anak-anak, apakah dalam keadaan sehat atau tergoncang jiwanya, melihat kondisi pelaku ${ }^{14}$ untuk dapat meminta pertanggungjawabannya jikalau terbukti melakukan pelanggaran atau kejahatan.

Sedangkan sudut pandang jika ditinjau dari aspek sosiologis yaitu dilihat dari aspek masyarakat, hukum yang hidup dalam masyarakat, kelembagaan sosial, dan pranata sosial, yaitu menyikapi bahwa dalam kesetaraan gender memang mendominasi kaum laki-laki lebih kuat dibandingkan perempuan sehingga kaum dengan kekuatan itu kaum pria menjadi pelindung perempuan, dimana lahirnya atau adanya kesetaraan gender dalam masyarakat, berasumsi bahwa masyarakat harus adanya kesetaraan atau persamaan hak, dan keadilan serta kepastian hukum untuk dapat menikmati bersama hasil atau buah dari suatu pembangunan yang ada, dan setiap orang dapat berpartisipasi dalam keikutsertaannya dalam pembangunan tanpa adanya tekanan atau intimidasi.

Sebagian masyarakat menyadari perlu adanya keadilan dalam gender khusunya dalam hal terkecil yaitu rumah tangga, rumah tangga yang didasarkan atas keadilan dan kesetraan gender yaitu masing-masing menyadari akan tugas dan tanggungjawabnya yang ada, kekerasan atau konflik dalam rumah tangga dapat dihindari jika ada saling pengertian, bertanggungjawab, saling memahami dan mengerti akan peran masingmasing, harmonis, adil, kelanggenan dalam membina rumah tangga yang sejahtera.

13 Zuhriah, E. (2008). Gender Dalam Perspektif Hukum dan HAM di Indonesia (Seri Bunga Rampai), Malang : UIN Malang Press, h. 24.

14 Gandhi, L. L. M. (2012). Disiplin Hukum Yang Mewujudkan Kesetaraan Dan Keadilan Gender, Jakarta : Yayasan Pustaka Obor Indonesia, h. 61. 
Peran dan tanggungjawab serta menyadarinya maka dapat dikatakan bahwa pemenuhan akan hak dapat berjalan sebagaiman mestinya, namun bentuk ketidaksetaraan gender dalam masyarakat dapat terjadi jikalau pihak laki-laki lebih mendominasi segala aspek bidang kehidupan, dan yang paling utama menghilangkan pemikiran adanya budaya patriarkhi dalam segala aspek kehidupan, tetapi ada juga dari menganggap kesetaraan gender lebih didominasi oleh pihak laki-laki, karena menganggap perempuan mempunyai keterbatasan, sehingga pihak laki-laki dianggap mampu dan dapat mengatasi segala persoalan yang ada ${ }^{15}$.

Namun, dengan segala keterbatasan yang ada, bukan berarti bahwa perempuan juga memiliki haknya masing-masing, semuanya dikembalikan kepada pribadi masing-masing individu agar tercipta rasa tentram dalam masyarakat, jika kesadaran diri belum ada, maka tidak menyadari tanggungjawab dan perannya maka akan timbul ketidaksetaraan gender di dalam aspek bidang kehidupan.

\section{Kendala / Hambatan dalam Kesetaraan Gender}

Kesetaraan gender selama ini masih terdapat kendala atau yakni :

a) Kurangnya Akses Pendidikan

Laki-laki dan perempuan harus mendapatkan jenjang pendidikan yang tinggi, namun karena sudah menikah, perempuan diharuskan untuk mengurus rumah tangganya atau keluarganya, sehingga mengakibatkan tidak dapat lagi melanjutkan sekolahnya ke jenjang yang lebih tinggi.

b) Pernikahan Usia Dini

Pernikahan ini bisa terjadi karena kurangnya pengawasan keluarga, sebagai orang tua sehingga pergaulan anak yang bebas, terjerat hutang dan menjual anaknya, bahkan adanya anggapan bahwa dengan menikahkan anaknya maka tanggungjawab orangtua selesai, belum adanya atau tumbuhnya kesadaran dalam diri, harus adanya perubahan maindset dalam pemikiran.

c) Ancaman Hukuman Kepada Pelaku Kekerasan Rumah Tangga dianggap Ringan Makin maraknya kekerasan terhadap perempuan, baik dalam rumah tangga ataupun diluar rumah tangga, ada yang takut dan tidak berani melaporkan tetapi ada juga lebih memilih perceraian dibandingkan melapor kepada pihak aparat penegak hukum, disamping itu ancaman hukuman dianggap ringan oleh korban dan kebanyakan diselesaikan dengan musyawarah atau mediasi ${ }^{16}$.

d) Masih kurangnya akses perempuan dalam pengambilan keputusan serta berpartisipasi penuh di dalam bidang politik dan pemerintahan di masyarakat, ini bisa dianggap juga sebagai ketidakadialn dalam gender, karena setiap orang baik laki-laki dan perempuan mempunyai hak yang sama dalam segala aspek politik dan juga dalam pemerintahan ${ }^{17}$

\section{PE N U T P}

Kesetaraan gender dalam sudut pandang nomratif dengan mendasarkan pada aturan dan norma yang berlaku dalam masyarakat serta dilaksanakan dengan penuh konsisten

15 Waston, M. (2014). "Pengarusutamaan Gender dalam Program Pembangunan", Jurnal Pendidikan Ilmu-Ilmu Sosial, 6 (2), h. 126.

16 http://ditjenpp.kemenkumham.go.id/hukum-pidana/653-undang-undang-no-23-tahun-2004tentang-penghapusan-kekerasan-dalam-rumah-tangga-uu-pkdrt.html, (Diakses Kamis, 26 Desember 2019).

$17 \mathrm{http}$ ///kapalperempuan.org/enam-masalah-perempuan-indonesia, (Diakses Jumat, 27 Desember 2019).

160 |S A S I Vol. 26 No.2, April - Juni 2020 
sedangkan dalam sosiologis didasarkan pada cara pandang msyarakat yang menganggap bahwa kesetaraan gender dapat terlaksana jika adanya persamaan akan hak, keadilan dapat terpenuhi dan terlaksana.

Kendala dalam hambatan dalam pelaksanaan kesetaraan gender yaitu kurangnya akses pendidikan, pernikahan usia yang dini (usia muda), ancaman hukuman bagi elaku kekerasan dalam rumah tangga dinilai masih ringan dan masih terbatasnya akses perempuan dalam berpartisipasi dalam pengambilan keputusan dalam bidang politik dan pemerintahan.

\section{DAFTAR PUSTAKA}

\section{Buku}

[1] Fakih, M. (2007). Analisis Gender dan Transformasi Sosial, Yogyakarta: Pustaka Pelajar.

[2] Gandhi, L. L. M. (2012). Disiplin Hukum Yang Mewujudkan Kesetaraan Dan Keadilan Gender, Jakarta : Yayasan Pustaka Obor Indonesia.

[3] Graham, D. S. (2018). Keberagaman Gender di Indonesia, Jakarta : Yayasan Pustaka Obor Indonesia.

[4] Luhulima, A. S. (2014). CEDAW : Menegakkan Hak Asasi Perempuan, Jakarta : Yayasan Pustaka Obor Indonesia.

[5] M. Echols John dan Sadily, H. (1983). Kamus Inggris Indonesia, Jakarta: Gramedia.

[6] Soekanto, S \& Mamudji, S. (2015). Penelitian Hukum Normatif (Suatu Tinjauan Singkat), Jakarta : Rajawali Pers.

[7] Zuhriah, E. (2008). Gender Dalam Perspektif Hukum dan HAM di Indonesia (Seri Bunga Rampai), Malang : UIN Malang Press.

\section{Jurnal}

[8] Amalia, M. (2011). "Kekerasan Perempuan Dalam Perspektif Hukum Dan Sosiokultural", Jurnal Wawsan Hukum, 25 (02).

[9] Efendy, R. (2014). “Kesetaraan Gender Dalam Pendidikan”, Jurnal Al-Maiyyah, $07(02)$.

[10] Hasan, B. (2019). “Gender dan Ketidakadilan”, Jurnal SIGNAL, 7 (1).

[11] Krisnalita, L. Y. (2018). "Perempuan, HAM, dan Permasalahannya Di Indonesia", Binamulia Hukum, 7 (1).

[12] Prantiasih, A. (2012). "Hak Asasi Manusia Bagi Perempuan", Jurnal Pendidikan Pancasila dan Kewarganegaraan, 25 (1).

[13] Ulfatun, H dan Najahan, M. (2017). "Gender And Politics : Keterlibatan Perempuan Dalam Pembangunan Politik", SAWWA, 12 (3).

[14] Waston, M. (2014). "Pengarusutamaan Gender dalam Program Pembangunan", Jurnal Pendidikan Ilmu-Ilmu Sosial, 6 (2).

\section{Online/World Wide Web}

[15] http://ditjenpp.kemenkumham.go.id/hukum-pidana/653-undang-undang-no-23tahun-2004-tentang-penghapusan-kekerasan-dalam-rumah-tangga-uu-pkdrt.html, (Diakses Kamis, 26 Desember 2019).

[16] http://kapalperempuan.org/enam-masalah-perempuan-indonesia, (Diakses Jumat, 27 Desember 2019). 